\title{
APPLICATION OF METHODS FOR PLAYING \\ WALL-BASED CANCEL TO IMPROVE ACTIVITIES AND LEARNING OUTCOMES STUDENT STUDENTS SOCIAL SCIENCE WORLD MATERIAL II
}

\author{
Kusno Sugio \\ Pubic Middle School 1 \\ e-mail: kusno520@gmail.com
}

\begin{abstract}
Abstrak
The study of the application of pictorial word guessing methods to improve the activity and learning outcomes of class IX A social studies subjects in World War 2 material and consequently in Sugio 1 Public Middle School 2018/2019 school year aims to apply the method of guessing words to improve learning activeness and results students of class IX A on social studies subjects especially material for World War 2 and consequently even semester 2018/2019 as many as 24 students. The method of data collection is done through tests, observations, documents and interviews. The data analysis technique was carried out by analyzing the average score of the students' performance in the teaching and learning activities. Determine student learning outcomes. Calculates the percentage of students who have successfully taken the test. Data collection. This class action is carried out in 2 cycles consisting of the planning, implementation stages. Observation and reflection. In cycle 1 to cycle 2 there is an increase in the results of completeness of learning outcomes of students.
\end{abstract}

Keywords : Picture word guessing games, Active students in learning

\section{INTRODUCTION}

Professionalism of a teacher is needed to create a creative, effective, and efficient learning process in developing students' abilities that have diverse characteristics. The teacher must also use learning methods and media by using appropriate and interesting learning tools in an effort to improve the quality of learning The success of teaching and learning activities is determined by the exact use of teaching methods and strategies used by the teacher in accordance with the formulated teaching goals. Teaching materials delivered without regard to the use of methods and strategies will not be well received by students. Clearly, it is necessary to think about 
the strategies used by the teacher for students. Because the selection and use of the right strategy will be able to help the success of the teaching program. Social science is one of the subjects taught in schools starting from the level of basic education to college. In achieving the objectives of social studies learning sometimes faces several obstacles that make social studies learning less attractive to students. Rahmantina (2007: 79) identified these constraints as follows:

"(1) social science material has many abstract concepts, (2) solid learning material, while allocated time is very limited, (3) students lack ability to solve problems, (4) low enthusiasm or student motivation. (5) the learning atmosphere is less lively or rigid, (6) the teacher still uses teacher-centered learning model with conventional methods. (7) learning media are very lacking or even not supportive.

This basic assumption causes the competency of integrated social studies subjects to be less than optimal, especially for Grade IX students at 1 Sugio Public Middle School. This results in an unpleasant learning atmosphere that makes the material taught less interest and boring for students, especially social science History, although in KBM the teacher has used learning media by showing good pictures using OHP, Audio visual, VCD and slides but still boring for students. The facts on the ground show that the learning activities carried out by social studies subject teachers especially those in Sugio 1 Public Middle School become a tendency that on average students find it difficult to meet the minimum completeness criteria that have been set, namely with KKM 75. This tendency is also an obstacle for teachers concerned because the achievement of mastery of learning material is very low. Students from this school are middle-ability students with average mastery of concepts, but in applications in the field it is seen that students' ability to understand the material provided by teachers is still very low, students tend to be passive and bored in learning. And this means that the average student achievement in learning in the social studies field is still very low. Therefore, researchers apply the method of word guessing with media images to attract the attention of students to learn. Based on the background of the problem above the research problem was formulated as follows "how is the activeness and learning outcomes of social studies subjects integrated with World War II material and consequently through the method of guessing the pictorial word." In class IX A students in State Junior High School 1 of 2018/2019 Academic Year Learning is a business process carried out by someone to obtain a change in behavior as a whole, as a result of his own experience in interaction with the environment (Slameto, 2003: 2). Based on the opinions above the learning process occurs thanks to students getting something that is in the environment. Behavior changes occur because of effort and from the change there will be acquired new skills. In learning students must seek active participation, involvement, directly in the learning process, increasing interest, and guiding to achieve predetermined learning goals. In general, learning outcomes can be interpreted as a result achieved after the learning process. Sudjana (2010: 22), learning outcomes are abilities possessed by students after receiving learning experiences. Learning outcomes 
can be improved by the process of learning through conscious effort carried out systematically leading to positive change.

The method of play is a way of presenting teaching materials where students do games to obtain or find certain understanding and concepts. Through this method, students carry out activities (games) within the framework of the teaching and learning process, both individually and in groups. Eko Susanto (2009: 20) states that the game can function as follows: "games provide enlightenment when experiencing saturation, instill material In memory becomes longer, and can also function as an reinforcer in making conclusions at the end of the meeting. With games, the class will become more alive, the learning atmosphere is full of cheerful, uplifting. In addition, students will become confident and pro active in taking lessons ". In general, learning outcomes can be interpreted as a result achieved after doing the learning process. Sudjana (2010: 22), learning outcomes are abilities possessed by students after receiving learning experiences. Learning outcomes can be improved by the process of learning through conscious effort carried out systematically leading to positive change.

Benjamin Bloom divides learning outcomes into three domains, namely the cognitive, affective and psychomotor domains. (Supriono. 2012: 5) a. Cognitive domain. The cognitive domain is related to intellectual learning outcomes consisting of six aspects, the six levels or aspects in question are (1) Knowledge (2) Understanding (Comprehension), (3) Application (Application), (4) Analysis (Analysis ), (5) Synthetic (Synthesis), (6) Evaluation (Evaluation), refers to the ability to give consideration to material values for a particular purpose $b$. The affective domain of the affective domain deals with attitudes and values consisting of five aspects. The five aspects start from the basic or simple level to the complex level as follows: (1) Receiving ability, (2) Responding, (3) Award (Valving), (4) Organizing (Organization), (5) Characteristics of value (Characterization by value) c. Psychomotor domains Psychomotor learning is seen in the form of skills (skills) that involve the function of the nervous system and muscles and psychological functions and the ability to act individually. Based on the understanding of the learning outcomes, it can be concluded that the learning outcomes are not only something that can be measured quantitatively but also qualitatively so that the assessment can use tests or non-tests aiming to determine student learning outcomes in terms of affective, cognitive and psychomotor domains. Social Sciences is a subject that studies social life based on geographical, economic, sociological, anthropological, administrative and historical material. (Dekdiknas, 2003). In Permendiknas (2006: 125), it was stated that social studies examines a set of events, facts, concepts, and generalizations relating to social issues. Organizing social studies subject matter for the SMP / MTS level integrated approach, meaning that the subject matter developed and compiled does not refer to separate disciplines but refers to the real-life aspects (factual / real) of students according to the characteristics of age, level of development thinking, and habitual behavior and behavior. According to Agus Suprijono (2009: 128) the word guess learning model is pembelajaran a learning model that uses card puzzle media that pairs with answer puzzle cards ". This word guessing game using card media is carried 
out by means of matching cards to puzzle questions with the right answer cards. Inside the question card contains puzzles that provoke the child to find answers to the questions of the puzzle. Through the word guessing game, besides children becoming interested in learning, it also makes it easier to embed the concept of understanding vocabulary in children's memories. So, the teacher invites children to guess words by using card media from cardboard in subjects. Principles or characteristics of guessed models said Agus Suprijono (2009: 130), namely: 1) Learning takes place pleasantly 2) Students are directed to active 3) Using card media. The media used according to Agus Suprijono (2009: 132) are: a) $10 \times 10 \mathrm{~cm}$ card size and fill in the characteristics or other words that lead to the answer (term) on the card you want to guess. b) A $5 \times 2 \mathrm{~cm}$ card for writing predictable words or terms (this card will be folded and taped to the forehead or tucked in the ear, in a pocket or worn.

The model learning scenario guesses words according to Agus Suprijono (2009: 131), namely: a) The teacher explains the competencies to be achieved or material \pm 40 minutes. B) The teacher tells the child to stand in pairs in front of the class c) A child is given a $10 \times 10$ card $\mathrm{cm}$ which will be read to the partner. Another student is given a card measuring $5 \times 2 \mathrm{~cm}$ whose contents should not be read (folded) and then placed on the forehead or tucked in the ear. d) While the child carries a $10 \times 10 \mathrm{~cm}$ card reads the words written in it while the partner guesses what is meant on the card $10 \times 10 \mathrm{~cm}$. the right answer if it matches the contents of the card affixed to the forehead or ear. e) If the answer is correct (according to what is written on the card) the couple may sit. If it is not right at the appointed time, you can direct it with other words as long as you don't give the answer immediately.

\section{Examples of Sentences Guess words}

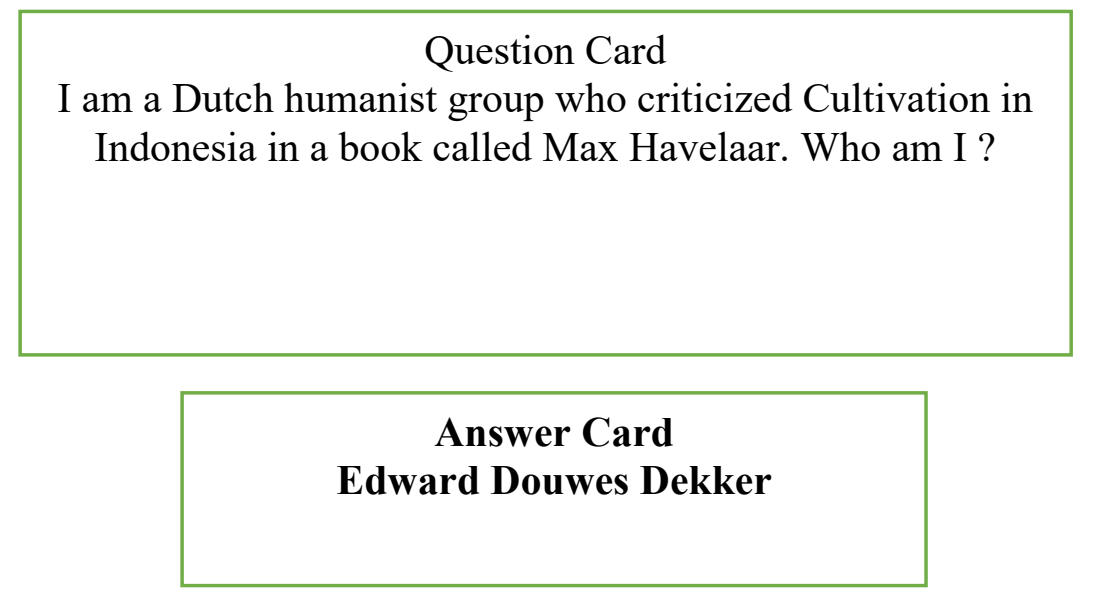

This word guessing game is intended to train children in remembering and using concepts that have been learned and even those that have only been discovered or discovered during the game, without hesitation or fear of being wrong, and of course at the same time training children's speech and how to identify things by making sentences ( Nurati, 2012). So, the word guess learning model is one of the Cooperative Lerning 
learning models, with interesting learning processes that can make children interested or interested in learning, making it easier to embed concepts in children's memories. In addition, children are also directed to actively ask, question, and express ideas. Using pictorial guessing learning models in integrated social studies introductory material, the entry of foreign powers in the archipelago and consequently is expected to increase the activity and learning outcomes of class IX 1 Sugio Kab Middle School students. . Lamongan. For more details, the following scheme of mindset, namely

Activity and learning outcomes of class X Sugio Lamongan State Middle School students

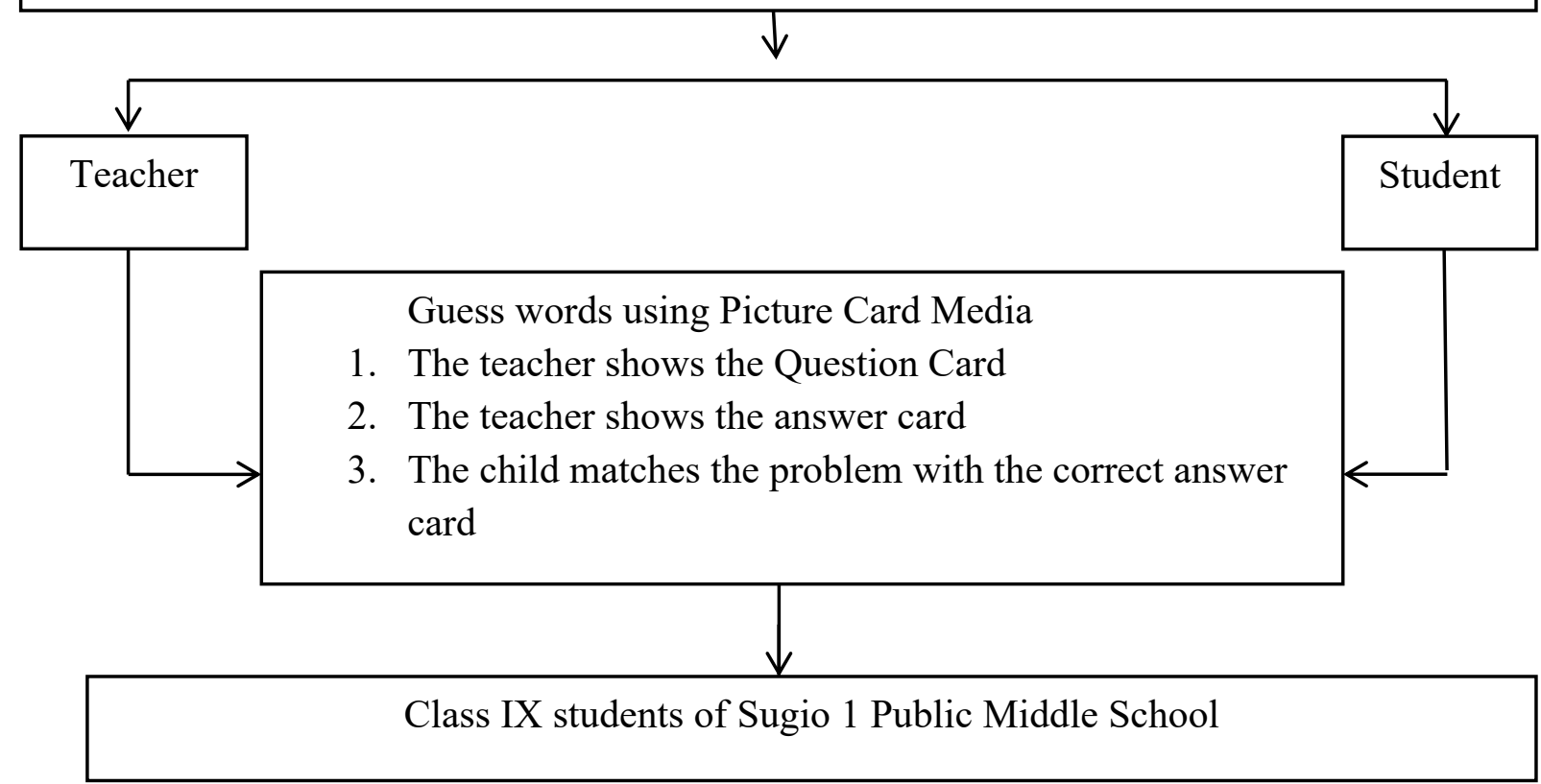

\section{RESEARCH METHODS}

In a research method research plays an important role because it will be a clue to the implementation of activities that take place in whole stages to be carried out documented in the actions taken. For this reason, the following will be explained about A. Type of Research. B. Place and Time of Research. C. Subjects and Data Sources of Research. D. Data Collection Methods Data analysis techniques. E. Research procedures. Based on the type, the research used by researchers is class action research (PTK). Ebbut, 1985 (in R. Wiriatmaja. 2005: 12) describes action research as a systematic study of efforts to improve the implementation of educational practices by a group of teachers by carrying out actions in learning, based on their reflection on the results of these actions. First (Sugio Middle School 1) Lamongan. In this study, the subjects of the study were Class IX A students of Sugio 1 Public Middle School and the 
data sources to be used in this study include: (1) Information from resource persons consisting of students of class IX B, and teachers of social studies, (2) Documents in the form of Curriculum, Learning Implementation Plans, learning outcomes of class IXA students and photos of learning processes In this study data were obtained in several ways, namely: (1) tests, (2) observation, (3) documents, (4) interviews Because this research belongs to descriptive qualitative research. This analysis is intended to describe the level of student activity in teaching and learning activities as well as the success of students understanding learning using the pictorial word guessing method. The steps taken in collecting data to describe the level of students' ability to understand social science learning are as follows:

1) Calculating the average score for the performance of students in KBM activities is Number of active students

Active quality $=\longrightarrow$ X 100\%

The number of students

Description of Rating:

Value $91 \%$ - 100\% $=$ Very active

Value $71 \%-90 \%=$ Active

Value $61 \%-70 \% \quad=$ Quite active

Value $\geq 61 \% \quad=$ Less active

2) Determine student learning outcomes with the formula:

Correct answer score

Value $=\frac{\text { Maximum score }}{\text { C } 100 \%}$

Description of Rating:

$\begin{array}{ll}\text { Value } 91-100 & =\text { Very good } \\ \text { Value } 81-90 & =\text { Good } \\ \text { Value } 71-80 & =\text { Enough } \\ \text { Value } \geq 60 & =\text { Less }\end{array}$

(adapted from Kunandar 2013)

3) Calculating the percentage of students who successfully take the test is

The number of students who succeed in a test

Number of students taking the test

X $100 \%$

The procedure used in classroom action research is in the form of a series of cycles consisting of several stages, namely planning, implementation, observation and reflection. Indicator of success in this study is if the activeness and learning outcomes of social studies obtained by students in a classical manner there are at least $80 \%$ of 
students obtain a value above the lowest value limit, the lowest score obtained by students after evaluation so that it is assumed to be the minimum completeness criteria (KKM).

\section{RESULT AND DISCUSSION}

The initial conditions of class IX A students of SMP Negeri 1 Sugio even semester semester 2018/2109 are the low number of students or the percentage of students who are active and respond to teacher lessons, namely from 24 students who are not active or do not respond to learning. Which means that overall students who are active are only about $33.33 \%$ or around 8 students in learning activities, inactive students around $66.66 \%$ or 16 students. While the level of student understanding of the learning material based on student learning shows that students' understanding is still low, namely from 24 students, only $45.71 \%$ of students or around 16 students score above the KKM limit (value 75 ) and $68.57 \%$ or around 13 students from 24 students are under the KKM. Based on the above, research needs to be done to improve student activity and learning outcomes in social studies. The results of this first and second cycle research are: The picture learning process of guessing is carried out in three stages. The first phase of service activities begins with a greeting and checks the number of attendees, teachers in the field condition the class then proceed to the introduction of the topics to be discussed, at this stage the author uses lecture methods and questions and answers about cooperation and benefits resulting from good cooperation. Next the teacher explains about the picture word guessing game that will be played in the first cycle. In the game the teacher asks students to stand in pairs in front of the class. A child is given a card measuring $10 \times 10 \mathrm{~cm}$ which will be read to the pair. Another student is given a card with a size of $5 \times 2$ cmyang, the contents should not be read (folded) then taped to the forehead or slipped in the ear. $\mathrm{cm}$. the right answer if it matches the contents of the card affixed to the forehead or ear. If the answer is correct (according to the written card) then the couple may sit. If it is not right at the time that has been set, you can direct it with other words as long as you don't give the answer immediately. Based on the results of observations / evaluations and data analysis of the implementation of the first cycle, not all children are able to master the material in the word guessing game. This can be seen from the implementation of actions in the first cycle is still far from expectations. What is applied by the teacher in understanding the lesson through guessing games has not been able to fully attract students' attention to the material taught. The failures and successes in the first cycle are as follows: 1 . From the teacher aspect, there are some failures in the first cycle, namely the teacher is still having difficulty in inviting children to guess words because it looks like children are still distracting others and are still confused in word guessing, and teachers those who are not ready to provide lesson material in the first cycle of meeting I, this can be seen in the picture on the question card that is not colored so it is less attractive to children. 2. From the aspect of students. From the aspect of students, that is, in the first cycle, there are still many who have not been able to understand and master the word guessing game, there are still around 15 out of 24 students. 
In the class that incorrectly matches the words in the answer card and question card so that the assessment indicator is said to have not fulfilled the completion according to the KKM. But students are good at showing the characteristics of authenticity and want to work, play diligently and carefully. As for the results of the first cycle based on the post test results, the conclusions are as follows: that there is an increase in the students' active and understanding social studies subjects in World War 2nd and the consequences. This can be indicated by the percentage increase in the number of students who are active in learning experiencing an increase of $70.83 \%$ or about 18 students but classically have not experienced increased activity due to the value of students active in learning $\leq 60 \%$ which means being in sufficient quality, increasing student understanding of results learning reaches around $66.66 \%$ or about 16 students have a value above the KKM limit (value $\geq 75$ ) and the remaining $33.33 \%$ or around 8 people whose values are below the KKM limit in other words have not been completed. For a clear analysis of the completeness of student learning outcomes can be seen in the table as follows

Table 1

Analysis of completeness of student learning outcomes in cycle 1

\begin{tabular}{|c|c|c|c|c|}
\hline No & Completion & Score & Total Student & Percentage \\
\hline 1 & Not Completed & $0-69$ & 16 & $66,66 \%$ \\
\hline 2 & Complete & $70-100$ & 8 & $33.33 \%$ \\
\hline \multicolumn{2}{|c|}{ Total } & & $100 \%$ \\
\hline
\end{tabular}

From the above reflexes it is deemed necessary to hold a second cycle. So that the constraints Kendal experienced in the first cycle can be overcome properly. As for the results of the study attached. Based on this, the second cycle is held.

Based on the reflection of the first cycle that was used as a reference in the implementation of the second cycle, the author began to prepare a detailed Learning Preparation Plan (RPP) and covers all elements and stages of the implementation of the second cycle. The next step in the picture learning process for pictorial words is carried out in three stages. The first phase of service activities begins with an introduction with greetings and checks the number of attendance of students, the teacher in the study conditions.

The class then continued on the introduction of the topics to be discussed, at this stage the author used the lecture method and questions and answers about the cooperation and benefits resulting from good cooperation. Next, the teacher explains about the picture guessing game that will be played in the second cycle. In the game the teacher asks students to stand in pairs in front of the class. A child is given a card measuring $10 \times 10 \mathrm{~cm}$ which is then read to the pair. Another student is given a card measuring $5 \times 2 \mathrm{~cm}$ whose contents should not be read (folded) then affixed to the forehead or tucked in the ear. While the child carries a $10 \times 10 \mathrm{~cm}$ card reads the words written in it while the partner guesses what is meant in card $10 \times 10 \mathrm{~cm}$. the right answer if it matches the contents of the card affixed to the forehead or ear. If the answer is correct (according to what is written on the card) the couple may sit. If it is not right at the time that has been set may direct with other words as long as do not immediately give the answer. From the reflexion Based on the results of observation / evaluation and 
analysis of the implementation of the second cycle, the implementation of cycle II actions has been implemented well and optimally. the following: 1. From the aspect of the teacher, and the teacher is so ready.

In providing subject matter in the second cycle of the first and second meetings. This can be seen from the readiness of the teacher in providing teaching and learning materials well and attractively, able to direct and guide students in an orderly, orderly and enthusiastic way of playing words so that students are able to master the game and master the lessons in the word guessing game. The success achieved by students in cycle II is: a) Children are able to think fluently / fluence. B) Able to adapt quickly and easily. C) Able to work together diligently and meticulously in guessing words.d) Able to develop and master the material and the game without help from the teacher.

As for the results of cycle II based on the results of the post test, the conclusions are as follows: that there is an increase in students' activeness and understanding in social Sciences subjects in World War 2 along with their consequences. This can be indicated by the percentage increase in the number of students who are active in learning experiencing an increase of $70.83 \%$ or about 18 students in the first cycle up to $91.66 \%$ or around 22 students from 24 active people which means it is above the activeness score $>60$ upwards, which means good activity. in the KBM activities, the remaining 2 people who were in quite active quality and were randomly experienced increased because the number of active students reached $80 \%$, an increase in students' understanding of learning outcomes reached around $100 \%$ or around 35 students had value above the KKM limit (value $\geq 75$ ). For more details the analysis of completeness of student learning outcomes can be seen in table 4.1.2. as follows

Table 2.

Analysis of completeness of student learning outcomes in cycle 2

\begin{tabular}{|c|c|c|c|c|}
\hline No & Completion & Score & Total Student & Percentage \\
\hline 1 & Not Completed & $0-69$ & 0 & 0 \\
\hline 2 & Complete & $70-100$ & 24 & 100 \\
\hline \multicolumn{2}{|c|}{ Total } & & 100 \\
\hline
\end{tabular}

The table above shows the accuracy of student learning outcomes. Therefore the research was stopped until cycle II. The learning process uses the method of guessing pictorial words on the subjects of the entry of foreign powers in the archipelago and its consequences in two stages, namely cycle I and cycle II, each cycle consisting of two meetings. Learning in Cycle I and Cycle II uses the same sequence but certainly not exactly the same because in Cycle II there have been improvements in the results of reflection in Cycle I, so that the results of Cycle II are more maximal. The use of word cards in word guessing games for students in class IX A Sugio 1 Public Middle School in the second cycle showed a very significant increase when compared to the first cycle and the stage before learning. In the first cycle, the average teacher teaching activity was enough while the learning activities of the students were in the less category. Based on the learning process of the first cycle there are several weaknesses amongx the teachers who are less able to direct students, providing colorless question cards so that it is less attractive for children in guessing words, there are some children who are still wrong in matching question cards and answer cards in word guessing. 
Based on these weaknesses researchers and teacher class concluded learning cycle I has not been successful and must be followed kesiklus II by correcting the deficiencies found in cycle I. These improvements in the form of teachers should better guide children to get to know the words on the card, understand fill in the question.

And able to answer well and correctly In the second cycle, teacher teaching activities are seen as active learning students. Students have been able to do their own steps properly and correctly, almost all students have been able to master the game and the words in the game properly and correctly. Based on the evaluation results of the assessment above, it was found that the use of the Guess Word method can increase student activity and learning outcomes which can be seen in the graph 4.1 below:

Graph 4.1 Graph of student learning achievement results of the research cycle I and cycle II

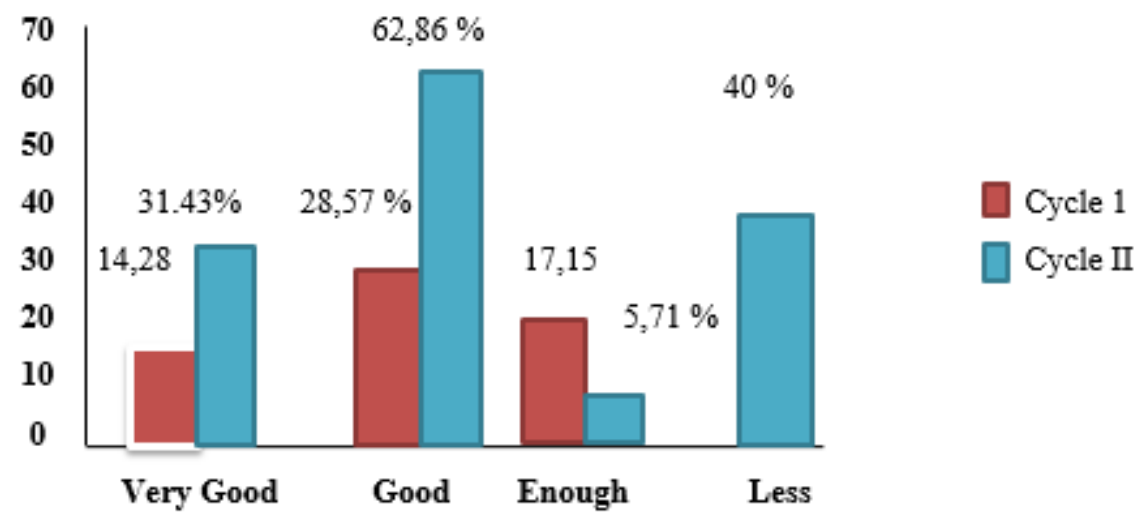

(source: Data Has been processed in the attachment)

The graph provides information that the average value of the class has increased from cycle 1 to cycle II. The application of the guesswork model of pictorial words to the students of Akelas IX A Sugio Middle School 1. in the first cycle around 14.28\% or students are at Very Good (SB) with the acquisition value of learning outcomes around 91-100, which is Good (B) 28.57\% with learning outcomes ranging from 81-90 and Sufficient qualifications (C) range from $17.15 \%$ of students with learning achievement scores ranging from 71-80 which means that overall the number of students above the completeness threshold $\geq 7$ ranges from $60 \%$, while students who are less qualified are still very much around $40 \%$ of students with acquisition scores learning outcomes ranged from $>60$. Many students who have qualifications ranging from $>60$ or less, which means that students have not yet finished learning. This means that the learning process using the picture word guess method has not yet reached the indicators of success. II in cycle II. An increase in student learning outcomes. compared to the first cycle in the second cycle around $31.43 \%$ or students are in the Very good value (SB) with the acquisition value of learning outcomes around 91-100, which is Good value (B) $62.86 \%$ of students with learning outcomes ranges from 81-90 and the Enough qualification value $(\mathrm{C})$ ranges from $5.71 \%$ of students with the acquisition value of learning outcomes ranging from 71-80, while students who are qualified are less than> 
60 in Percentage. the absence of students who have qualifications ranging from $>60$ or less, which means students complete learning, this means that the learning process using the method of guessing words reaches an indicator of success. This shows the learning completeness of students in the second cycle has reached the success indicator according to the planned target.

\section{CONCLUSION}

Learning by applying the Guess Word method to integrated social studies subjects can improve the understanding and activeness of class IX A students of Sugio 1 Public Middle School 2018/2019 academic year. This effectiveness is evident from the increase in activeness and student learning outcomes in the first cycle of students who obtained an incomplete score below the completeness limit of $\leq 75$ ranging from $40 \%$ to a decrease in cycle 2 to zero\%. 2. The researchers' hypothesis which reads "Understanding and activeness of students in social studies learning can be improved by using the Guess Word learning method" can be accepted 1. Guess Word learning method as one method that can be used as an alternative to be used and very helpful for teachers in improving the quality of learning and learning outcomes for social studies and other subjects. The Word Guess Method is a learning method that combines learning and playing activities using basic materials of simple tools in the form of $10 \mathrm{x}$ 10 cartons for question cards and $5 \times 2$ for answer cards capable of attracting attention and regrowing students' passion for learning, especially social studies. Based on the results of the research that has been carried out, the following recommendations can be given: To increase the activity and learning outcomes of students, learning using the method of guessing the pictorial word can be used as an alternative choice in the process of teaching and learning activities as an option.

\section{REFERENCES}

BSNP, 2006. Curriculum Standard Content in the Field of Economics / Senior High School Studies, Jakarta: Ministry of National Education.

Ministry of National Education. 2003. Law on National Education System No. 20 of 2003. Jakarta: Citra Umbara.

Eko Susanto. 2009. 60 games to teach, open and close lessons. Yogyakarta: Our Granary.

Kunandar, 2003. Authentic assessment (Assessment of student learning outcomes based on the 2013 curriculum), Jakarta: PT. Rajawali Press.

Nana Sujana. 2010. Evaluation of Teaching Results. Bandung: PT Remaja Rosdakarya.

Nurati Nurati, 2012. summervina.blogspot.com. Guess the Learning Model. On access / 2012-05 / 
Slameto, 2003. Learning and the Affecting Factors. Jakarta: Rineka Cipta.

Suprijono, Agus. 2009. Cooperative Learning: Theory and Application of PAIKEM. Yogyakarta: Student Library.

Wiriatmaja, R. 2005. Classroom Action Research Methods. Jakarta: Rosdakary teenagers. 